\title{
Efek antibakteri dan penghambatan biofilm ekstrak sereh (Cymbopogon nardus L.) terhadap bakteri Streptococcus mutans
}

\author{
Zwista Yulia Dewi ${ }^{*}$, Asikin Nur**, dan Triana Hertriani ${ }^{* * *}$ \\ *Program Studi Magister IImu Kedokteran Gigi, Fakultas Kedokteran Gigi, Universitas Gadjah Mada, Yogyakarta, Indonesia \\ **Bagian Biomedika Kedokteran Gigi, Fakultas Kedokteran Gigi, Universitas Gadjah Mada, Yogyakarta, Indonesia \\ ***Bagian Biologi Farmasi, Fakultas Farmasi, Universitas Gadjah Mada, Yogyakarta, Indonesia \\ *JI Denta No 1 Sekip Utara, Yogyakarta, Indonesia; e-mail: zwistazwista@yahoo.com
}

\begin{abstract}
ABSTRAK
Pencegahan karies dapat dilakukan dengan beberapa cara. Salah satu cara yang dapat dilakukan dalam pencegahan karies adalah dengan mengontrol akumulasi plak pada permukaan gigi. Tanaman sereh (Cymbopogon nardus L.) mengandung senyawa yang mampu menghambat pertumbuhan bakteri dan biofilm. Penelitian ini bertujuan untuk mengetahui efek antibakteri dan penghambatan biofilm tanaman sereh terhadap Streptococcus mutans. Subjek penelitian adalah Bakteri S. mutans pada uji $\mathrm{KHM}_{90}$ sebanyak $6 \times 10^{8} \mathrm{CFU} / \mathrm{ml}$ dan pada uji penghambatan biofilm sebanyak $15 \times 10^{8} \mathrm{CFU} / \mathrm{ml}$. Tanaman sereh kering diekstraksi bertingkat dengan menggunakan petroleum eter dilanjutkan dengan menggunakan etanol $70 \%$. Uji aktivitas antibakteri dilakukan dengan uji penentuan $\mathrm{KHM}_{90}$ menggunakan metode mikrodilusi pada microplate flat bottom 96 wells. Bakteri disiapkan dengan membuat suspensi dalam media NB dan digunakan standar McFarland II $\left(6 \times 10^{8} \mathrm{CFU} / \mathrm{ml}\right)$. Uji aktivitas penghambatan biofilm dilakukan menggunakan metode mikrodilusi terhadap biofilm yang terbentuk pada microplate flat flexible U-bottom PVC 96 wells dengan pewarnaan menggunakan crystal violet $1 \%$. Bakteri disiapkan dengan membuat suspensi dalam media $B H I$ dan digunakan standar McFarland $\vee\left(15 \times 10^{8} \mathrm{CFU} / \mathrm{ml}\right)$. Hasil uji berupa optical density $(O D)$ dibaca dengan alat Bio-rad microplate reader Benchmark pada panjang gelombang $595 \mathrm{~nm}$. Nilai IC ${ }_{50}$ ditentukan dengan metode probit menggunakan program SPSS versi 15. Hasil dari penelitian yaitu pengukuran pada uji $\mathrm{KHM}_{90}$ menunjukkan bahwa $108,36 \% \mathrm{~b} / \mathrm{v}$ mampu menghambat pertumbuhan bakteri. Aktivitas penghambatan biofilm menunjukkan harga $\mathrm{IC}_{50}$ sereh adalah $0,137 \% \mathrm{~b} / \mathrm{v}$. Kesimpulan penelitian ini adalah terdapat efek antibakteri ekstrak sereh terhadap bakteri $S$. mutans ditunjukkan dengan diperolehnya $\mathrm{KHM}_{90}$ pada kadar konsentrasi $0,18 \% \mathrm{~b} / \mathrm{v}$ dan terdapat efek penghambatan biofilm ekstrak sereh terhadap bakteri $\mathrm{S}$. mutans ditunjukkan dengan nilai $\mathrm{IC}_{50} 0,137 \%$.
\end{abstract}

Maj Ked Gi Ind. Desember 2015; 1(2): 136 - 141

Kata kunci: sereh, Streptococcus mutans, antibakteri, penghambatan biofilm, plak gigi

\begin{abstract}
Antibacterial effect and biofilm inhibition Of Lemongrass extract (Cymbopogon nardus L.) against the growth of Streptococcus mutans. Caries prevention can be carried out by several methods. One of them is by controlling the plaque accumulation on the surface of the teeth. Lemongrass (Cymbopogon nardus $L$ ) is containing certain compound that can inhibit the growth of bacteria and biofilm. The objective of this research is to observe the influence of antibacterial and biofilm inhibition of lemongrass extract against the growth of S. mutans. Subjects were S. mutans bacteria on $\mathrm{KHM}_{90}$ test as much as $6 \times 10^{8} \mathrm{CFU} / \mathrm{ml}$ and on biofilm inhibition test as much as $15 \times 10^{8} \mathrm{CFU} / \mathrm{ml}$. Lemongrass was extracted using petroleum ether followed by using $70 \%$ ethanol. Antibacterial activity test carried out with $\mathrm{KHM}_{90}$ determination test using microdilution method on microplate flat bottom 96 wells. Bacteria were prepared by making a suspension in NB media and adjusted to McFarland II standard $\left(6 \times 10^{8} \mathrm{CFU} / \mathrm{ml}\right)$. Biofilm inhibition activity test was performed using microdilution method of the biofilm formed on microplate flat flexible PVC U-bottom 96 wells which were stained using $1 \%$ of crystal violet. Bacteria were prepared by making a suspension in BHI media and adjusted to McFarland $V$ standard $\left(15 \times 10^{8} \mathrm{CFU} / \mathrm{ml}\right)$. The result in the form of optical density (OD) was read by Bio-rad microplate reader Benchmark at a wavelength of $595 \mathrm{~nm}$. The value of $I C_{50}$ was determined by probit method using SPSS version 15. The results of this study of measurements on KHM $M_{90}$ test showed that $108,36 \% \mathrm{~W} / \mathrm{V}$ is capable of inhibiting the growth of bacteria. Biofilm inhibitory activity showed $I C_{50}$ lemongrass value was $0,137 \% \mathrm{~W} / \mathrm{V}$. The conclusion of this study is that lemongrass extract has antibacterial effect against bacteria S. mutans showed by $K H M_{90}$ obtained at concentrations of $0,18 \%$ w/ $\mathrm{V}$ and there is lemongrass extract biofilm inhibitory effect against the bacteria $S$. mutans indicated by $I C_{50}$ value $0,137 \%$.
\end{abstract}

Maj Ked Gi Ind. Desember 2015; 1(2): 136 - 141

Keywords: lemongrass, Streptococcus mutans, antibacteria, biofilm inhibition, teeth's plaque

\section{PENDAHULUAN}

Rongga mulut merupakan tempat berkumpulnya bakteri. Bakteri yang biasanya terdapat dalam mulut di antaranya adalah Streptococcus mutans, Streptococcus viridians, Staphylococcus aureus epidermidis, Staphylococcus pneumonia, dan 
Staphylococcus aureus. ${ }^{1}$ Karies pada gigi dapat berkembang jika di dalam mulut terdapat bakteri yang menimbulkan karies. Bakteri yang sering menyebabkan karies gigi adalah Streptococcus mutans. Bakteri tersebut banyak ditemukan di mulut dan merupakan penyebab utama karies gigi. ${ }^{2}$ Plak gigi atau lapisan biofilm memegang peranan penting dalam menyebabkan terjadinya karies. Bakteri S. mutans diakui sebagai penyebab utama karies karena mempunyai sifat asidogenik dan asidurik (resisten terhadap asam). ${ }^{3}$

Biofilm adalah kumpulan sel mikroorganisme, khususnya bakteri, yang melekat erat di suatu permukaan yang disertai dengan bahan-bahan organik dan diselimuti oleh matriks polimer ekstraseluler yang dikeluarkan oleh bakteri. ${ }^{4}$ Kontrol plak adalah penyingkiran plak mikrobial dan pencegahan terhadap akumulasinya ke permukaan gigi dan sekitarnya. Kontrol plak juga menghambat pembentukan kalkulus. ${ }^{5}$ Plak dapat dihilangkan dengan pembersihan secara mekanik dan penghambatan secara kimiawi. ${ }^{6}$ Pembersihan secara mekanis dapat dilakukan dengan menyikat gigi, sedangkan secara kimiawi dapat dilakukan dengan obat kumur. Salah satu tujuan menyikat gigi yaitu menghambat pertumbuhan bakteri plak. ${ }^{7}$ Penggunaan obat tradisional secara umum dinilai lebih aman karena memiliki efek samping yang relatif lebih sedikit daripada obat modern. ${ }^{8}$ Salah satu tanaman yang sering digunakan dalam pengobatan tradisional adalah sereh. Tanaman sereh merupakan tanaman herba annual, berasal dari Suku Poaceae yang digunakan sebagai pembangkit cita rasa pada makanan dan dipercaya pula dapat dimanfaatkan dalam pengobatan tradisional. Kandungan kimia dari sereh adalah minyak atsiri, saponin, polifenol dan flavanoid. ${ }^{9}$ Kandungan senyawa aktif tersebut, mengindikasikan sereh memiliki aktivitas antibakteri yang cukup besar..$^{10}$ Senyawa yang bertanggung jawab terhadap efek antibakteri sereh adalah golongan senyawa polifenol dan senyawa fenolik lain beserta derivatnya yang dapat menyebabkan denaturasi protein. Senyawa flavonoid berfungsi sebagai antibakteri dengan cara membentuk senyawa kompleks dengan protein ekstraseluler. Kompleks yang terbentuk mengganggu keutuhan membran sel bakteri dengan cara mendenaturasi protein sel bakteri dan merusak membran sel tanpa dapat diperbaiki lagi. ${ }^{11}$ Tanaman sereh mengandung senyawa saponin. Senyawa tersebut terbukti efektif menghambat pertumbuhan bakteri Gram positif. ${ }^{12}$ Hasil penelitian sebelumnya memperlihatkan bahwa sereh memiliki aktivitas antibakteri terhadap pertumbuhan Eschericia coli dan Staphylococcus aureus. ${ }^{13}$ Penelitian sebelumnya menunjukkan bahwa minyak atsiri sereh mempunyai kemampuan menghambat biofilm yang dibentuk oleh bakteri S. mutans. ${ }^{14}$

Penelitian ini menggunakan bakteri S. mutans karena merupakan bakteri yang dominan dalam pembentukan plak gigi dan salah satu bakteri utama penyebab karies gigi. Tujuan dari penelitian ini adalah untuk mengetahui apakah terdapat efek antibakteri dan penghambatan biofilm ekstrak sereh (Cymbopogon nardus L.) terhadap bakteri $S$. mutans.

\section{METODE PENELITIAN}

Surat ijin kelayakan etik diperoleh dari Unit etika dan advokasi Universitas Gadjah Mada Yogyakarta, No: 070/KKEP/FKG_UGM/EC/2010. Bahan utama penelitian ini adalah ekstrak tanaman sereh (Cymbopogon nardus L.) yang didapat dari Bagian Biologi Farmasi, Universitas Gadjah Mada, Yogyakarta. Bagian tanaman yang akan diuji yaitu tanaman sereh (Cymbopogon nardus L.) diidentifikasi di Laboratorium Taksonomi Tumbuhan, Fakultas Biologi, Universitas Gadjah Mada, Yogyakarta. Bakteri S. mutans diperoleh dari Laboratorium Pangan dan Gizi, Pusat Antar Universitas (PAU) UGM. Bakteri S. mutans diidentifikasi menggunakan pengecatan Gram. Hasil positif ditunjukkan dengan warna sel biru ungu berbentuk rantai pada pengamatan mikroskopik.

Uji penentuan $\mathrm{KHM}_{90}$ dilakukan dengan metode mikrodilusi. Bakteri dibuat suspensi dalam media Nutrient Broth (NB) dan digunakan standar McFarlandII $\left(6 \times 10^{8} \mathrm{CFU} / \mathrm{ml}\right)$ kemudian dilakukan pengenceran serial kadar masing-masing ekstrak sereh yaitu $0,023 \% \mathrm{~b} / \mathrm{v}, 0,045 \% \mathrm{~b} / \mathrm{v}, 0,091 \%$ $\mathrm{b} / \mathrm{v}$, dan $0,18 \% \mathrm{~b} / \mathrm{v}$ dengan larutan Dimethyl Sulfoxide (DMSO) sebagai pelarut. Kontrol pelarutnya digunakan DMSO dan kontrol positif digunakan Listerine ${ }^{\circledR}$ citrus. Larutan uji diletakkan 
pada microplate flat bottom 96 wells, dengan volume total $100 \mu \mathrm{l}$ tiap sumuran menggunakan micropippet. Pengujian dilakukan terhadap 1 plate uji dan 1 plate blanko. Plate uji berisi larutan ekstrak uji dengan penambahan suspensi bakteri $10 \% \mathrm{v} / \mathrm{v}$, sedangkan plate blanko berisi larutan ekstrak dengan penambahan larutan salin $10 \% \mathrm{v} / \mathrm{v}$ tanpa ditambahkan suspensi bakteri. Microplate flat bottom 96 wells ditutup dengan kertas parafilm dan dimasukkan dalam wadah khusus untuk meletakkan microplate flat bottom 96 wells dan diinkubasi selama 18-24 jam pada suhu inkubator $36,6^{\circ} \mathrm{C}$. Microplate flexible flat bottom 96 wells dikeluarkan dari inkubator kemudian larutan uji dibuang dan dicuci dengan air mengalir sebanyak 3 kali. Microplate flexible flat bottom 96 wells dikeringkan kemudian dalam tiap sumuran ditambahkan pewarna kristal violet $1 \%$ dalam air destilasi sebanyak $125 \mu \mathrm{l}$ dan diamkan selama 15 menit, kemudian dicuci lagi dengan air mengalir 3 kali dan didiamkan selama 15 menit. Kemudian ditambahkan etanol 96\% sebanyak $200 \mu \mathrm{l}$ dan didiamkan selama 15 menit. Hasil uji berupa optical density (OD) dibaca dengan alat Bio-rad microplate reader Benchmark, di Laboratorium Parasitologi Fakultas Kedokteran UGM.

Uji penghambatan biofilm dilakukan dengan metode mikrodilusi. Bakteri disiapkan dengan membuat suspensi dalam media Brain Heart Infusion (BHI) dan menggunakan standar McFarland $V$ $\left(15 \times 10^{8} \mathrm{CFU} / \mathrm{ml}\right)$ kemudian dilakukan pengenceran kadar masing-masing ekstrak yaitu $0,023 \% \mathrm{~b} / \mathrm{v}$, $0,045 \% \mathrm{~b} / \mathrm{v}, 0,091 \% \mathrm{~b} / \mathrm{v}$, dan $0,18 \% \mathrm{~b} / \mathrm{v}$ dengan DMSO sebagai pelarut. Kontrol pelarut dalam penilitian ini adalah DMSO sedangkan kontrol positif yang digunakan adalah Listerine $®$ citrus. Larutan uji diletakkan pada microplate flexible $U$ bottom 96 wells, dengan volume total $100 \mu$ liap sumuran menggunakan micropippet. Pengujian dilakukan terhadap 1 plate uji dan 1 plate blanko. Plate uji berisi larutan ekstrak uji dengan penambahan suspensi bakteri $10 \% \mathrm{v} / \mathrm{v}$, sedangkan plate blanko berisi larutan ekstrak dengan penambahan saline 10\% v/v tanpa ditambahkan suspensi bakteri. Microplate flexible $U$ bottom 96 wells ditutup dengan kertas parafilm kemudian diinkubasi selama 18-24 jam pada suhu inkubator $36,6^{\circ} \mathrm{C}$. Microplate flexible $U$ bottom 96 wells dikeluarkan dari inkubator kemudian larutan uji dibuang dan dicuci dengan air mengalir sebanyak 3 kali. Microplate flexible $U$ bottom 96 wells dikeringkan kemudian dalam tiap sumuran ditambahkan pewarna kristal violet $1 \%$ dalam air destilasi sebanyak $125 \mu \mathrm{l}$ dan diamkan selama 15 menit. Microplate flexible $U$ bottom 96 wells dicuci lagi dengan air mengalir 3 kali, didiamkan selama 15 menit. Kemudian ditambahkan etanol $96 \%$ sebanyak $200 \mu \mathrm{l}$ dan didiamkan selama 15 menit. Tahap terakhir adalah pemindahan $150 \mu \mathrm{l}$ larutan dalam microplate flexible $U$ bottom 96 wells ke microplate flat-bottom 96 wells menggunakan micropippet multichannel. Hasil uji berupa Optical Density (OD) dibaca dengan alat Bio-rad microplate reader Benchmark, di Laboratorium Parasitologi Fakultas Kedokteran UGM.

Nilai $\mathrm{KHM}_{90}$ merupakan konsentrasi terendah ekstrak yang masih mampu menghambat pertumbuhan S. mutans sebanyak $90 \%$. Persen penghambatan dihitung dengan rumus sebagai berikut:

\% penghambatan $\left.\left(1 \quad \frac{\text { OD sampel riji }}{\text { OD blanko sampel }}\right)\right) \times 100 \%$

Daya penghambatan dengan $\mathrm{IC}_{50}$ yaitu konsentrasi ekstrak yang masih dapat menghambat pembentukan biofilm sebanyak $50 \%$. Rumus \% penghambatan dihitung dengan cara:

\%s penghambatan $\left.\left(1 \quad \frac{\text { OD sampel uji }}{\text { OD blanko sampel }}\right)\right) \times 100 \%$

Nilai $I_{50}$ ditentukan dengan metode probit menggunakan program Statistical Package for the Social Sciences (SPSS) versi 15. Digunakan analisis probit untuk mencari konsentrasi yang mampu membunuh 50\% sampel (Inhibitory Concentration 50). Analisis probit digunakan untuk menguji tingkat konsentrasi terhadap respon sampel.

\section{HASIL PENELITIAN}

Telah dilakukan penelitian untuk mengetahui pengaruh konsentrasi ekstrak batang sereh (Cymbopogon nardus L.) sebagai bahan antibakteri dan penghambatan biofilm terhadap bakteri $S$. mutans. Penelitian ini menggunakan ekstrak sereh yang didapatkan dengan teknik maserasi menggunakan petroleum eter yang dilanjutkan 
dengan menggunakan etanol $70 \%$ hingga didapatkan ekstrak kental dan selanjutnya diujikan daya antibakterinya dan pembentukan biofilm menggunakan metode mikrodilusi. Hasil penelitian tercantum pada Tabel 1 dan Tabel 2. Kontrol pembanding Listerine ${ }^{\circledR} 45 \%$ dalam uji antibakteri menunjukkan daya penghambatan pertumbuhan bakteri sebesar 99,104\%. Berdasarkan data pada Tabel 1, diketahui bahwa ekstrak etanol sereh menunjukkan $\mathrm{KHM}_{90}$ pada kadar konsentrasi $0,18 \% \mathrm{~b} / \mathrm{v}$. Pada konsentrasi hambat minimal 90 dari ekstrak sereh lebih mampu menghambat lebih dari 90\% ditunjukkan dengan angka 108,36\%. Nilai tersebut lebih tinggi jika dibandingkan dengan kontrol Listerine ${ }^{\circledR}$.

Tabel 1. Persentase daya hambat pertumbuhan bakteri

\begin{tabular}{lll}
\hline Sampel Uji & Konsentrasi & $\begin{array}{l}\text { Penghambatan Pertumbuh- } \\
\text { an Bakteri }\end{array}$ \\
\hline \multirow{3}{*}{ Ekstrak batang } & $0,023 \% \mathrm{~b} / \mathrm{v}$ & $-20,61 \%$ \\
sereh & $0,045 \% \mathrm{~b} / \mathrm{v}$ & $47,07 \%$ \\
& $0,18 \% \mathrm{~b} / \mathrm{v}$ & $61,89 \%$ \\
Listerine $\mathbb{8}$ & $45 \% \mathrm{~b} / \mathrm{v}$ & $99,104 \%$ \\
\hline
\end{tabular}

Tabel 2. Persentase Penghambatan Biofilm

\begin{tabular}{lcl}
\hline Sampel Uji & Konsentrasi & $\begin{array}{l}\text { Penghambatan Pertumbuh- } \\
\text { an Biofilm }\end{array}$ \\
\hline \multirow{2}{*}{ Ekstrak batang } & $0,023 \% \mathrm{~b} / \mathrm{v}$ & $-42,09 \%$ \\
sereh & $0,045 \% \mathrm{~b} / \mathrm{v}$ & $29,63 \%$ \\
& $0,091 \% \mathrm{~b} / \mathrm{v}$ & $57,61 \%$ \\
Listerine ${ }^{\circledR}$ & $45 \% \mathrm{~b} / \mathrm{v}$ & $95,59 \%$ \\
\hline
\end{tabular}

Berdasarkan hasil pengukuran pada uji penghambatan biofilm pada konsentrasi $0,18 \% \mathrm{~b} / \mathrm{v}$ mampu menghambat pembentukan biofilm yaitu sebesar $95,59 \%$. Nilai tersebut lebih tinggi jika dibandingkan dengan kontrol.

Setelah diperoleh data \% penghambatan, nilai $I_{50}$ ditentukan dengan metode probit menggunakan program Statistical Package for the Social Sciences (SPSS)versi 15. Uji aktivitas penghambatan biofilm ini ditentukan pula harga $\mathrm{IC}_{50}$ (inhibitor concentration 50\%). Uji penghambatan pembentukan biofilm menunjukkan ekstrak sereh memiliki IC ${ }_{50}$ sebesar $0,137 \%$.

\section{PEMBAHASAN}

Hasil penelitian antibakteri menunjukkan adanya dose dependant activity ekstrak sereh yang ditunjukkan dengan meningkatnya aktivitas sesuai kenaikan konsentrasi. Hal ini sama juga terjadi pada hasil uji penghambatan biofilm. Semakin tinggi konsentrasi akan meningkatkan daya antibakteri. ${ }^{15}$

Media yang digunakan dalam uji aktivitas antibakteri adalah media NB karena media ini adalah media yang umum digunakan untuk uji aktivitas antibakteri. Berdasarkan beberapa penelitian, bakteri $S$. mutans juga dapat tumbuh baik di media Nutrient Broth (NB) dan Nutrient $\operatorname{Agar}(\mathrm{NA})$. $^{16,17}$ Suspensi bakteri pada uji aktivitas antibakteri digunakan standar Mc Farland II yaitu $6 \times 10^{8} \mathrm{CFU} / \mathrm{ml}$. Produk obat kumur Listerine ${ }^{\circledR}$ digunakan sebagai kontrol positif karena merupakan obat kumur yang telah beredar di pasaran dan banyak digunakan oleh masyarakat. Listerine ${ }^{\circledR}$ pada penelitian ini digunakan untuk kontrol metode. Pada konsentrasi $45 \% \mathrm{v} / \mathrm{v}$, Listerine $\AA$ mampu menghambat pertumbuhan bakteri sebesar 99,104\%. Hal tersebut dikarenakan Listerine ${ }^{\circledR}$ diketahui dapat menghambat pertumbuhan bakteri dengan baik. Listerine ${ }^{\circledR}$ mampu mengurangi bakteri salah satunya adalah $S$. mutans dalam mulut secara signifikan. ${ }^{18}$

Uji aktivitas penghambatan biofilm yang dilakukan pada penelitian ini prinsipnya hampir sama yang dilakukan pada uji aktivitas antibakteri. Media yang digunakan pada uji aktivitas penghambatan biofilm adalah media Brain Heart Infusion (BHI). Media $\mathrm{BHI}$ merupakan media yang baik untuk menumbuhkan bakteri $S$. mutans. Penelitian terdahulu menunjukkan penambahan suplemen seperti sukrosa $1 \%$ dapat mendukung pertumbuhan S. mutans lebih cepat dibandingkan kontrol yang tidak diberikan suplemen. ${ }^{19}$ Penelitian ini menggunakan media $\mathrm{BHI}$ dengan penambahan sukrosa $2 \%$ yang berdasarkan uji pendahuluan dapat menyebabkan pembentukan biofilm yang cukup. Suspensi bakteri yang digunakan dalam uji penghambatan biofilm setara dengan Mc Farland $V$ (konsentrasi $15 \times 10^{8} \mathrm{CFU} / \mathrm{ml}$ ) dengan konsentrasi yang lebih besar dibandingkan uji aktivitas antibakteri. 
Uji kuantitatif antibiofilm telah dilakukan menggunakan metode mikrodilusi dengan alat microtiter plate polystyrene 96 wells flexible yang melengkung pada bagian bawahnya. Pengujian ini dapat berupa matrix quantification assay yang dilakukan pada pewarnaan spesifik komponenkomponen matriks yaitu menggunakan kristal violet. Cara kerja uji penghambatan adalah biofilm setelah diinkubasi tidak langsung dibaca tapi diberi perlakuan dengan pemberian zat pewarna yaitu kristal violet. Pewarnaan dengan menggunakan kristal violet telah dimodifikasi guna meningkatkan keakuratannya dan memungkinkan identifikasi biofilm secara kuantitatif. Kristal violet merupakan pewarna dasar yang mengikat molekul bermuatan negatif dan polisakarida dalam matriks ekstraseluler. Oleh karena itu, kristal violet mewarnai sel-sel baik yang masih hidup maupun mati dan matriks biofilm. Wells diberi kristal violet kemudian dibuang dan dicuci dengan air mengalir maka kristal violet akan tetap melekat pada bagian yang terdapat biofilm. Cara ini dapat mendeteksi biofilm secara kuantitatif melalui pembentukan cincin berwarna ungu pada alat microtiter plate polystyrene 96 wells flexible. ${ }^{20}$

Uji aktivitas penghambatan biofilm ini ditentukan pula harga $\mathrm{IC}_{50}$ (inhibitor concentration $50 \%$ ). Uji penghambatan pembentukan biofilm menunjukkan ekstrak sereh memiliki $I_{50}$ sebesar 0,137\%. Semakin kecil harga $\mathrm{IC}_{50}$ maka semakin potensial efek hambat ekstrak tersebut dalam menghambat pembentukan bakteri. ${ }^{21}$

Batang sereh mengandung bermacammacam senyawa yaitu saponin, fenol, flavanoida, dan polifenol. Zat polifenol bekerja melalui penghambatan enzim oleh senyawa yang teroksidasi, kemungkinan melalui reaksi dengan gugus sulfhidril atau melalui interaksi yang non spesifik dengan protein mikroorganisme. Polifenol juga dapat menyebabkan denaturasi protein bakteri. ${ }^{22}$ Golongan senyawa lain yang berperan sebagai antibakteri yaitu flavonoid. Flavonoid diketahui memiliki kemampuan aktivitas transpeptidase peptidoglikan sehingga mengganggu pembentukan dinding sel terganggu, kemudian sel tidak dapat menahan tekanan osmotik internal yang dapat mencapai 5-20 atmosfer. Tekanan ini cukup untuk memecah sel apabila dinding sel dirusak. ${ }^{23}$
Kerusakan pada membran ataupun dinding sel menyebabkan keluarnya berbagai komponen penting dari dalam sel bakteri yaitu protein, asam nukleat, nukleotida, dan lain-lain yang berasal dari sitoplasma dan sel bakteri akan mengalami lisis. ${ }^{11}$ Tanaman sereh juga mengandung senyawa aktif saponin yang merupakan senyawa aktif yang bersifat antibakteri. Saponin bekerja dengan meningkatkan permeabilitas membran sel sehingga membran menjadi tidak stabil dan mengakibatkan hemolisis sel. ${ }^{24}$

\section{KESIMPULAN}

Terdapat efek antibakteri ekstrak sereh terhadap bakteri Streptococcus mutans yang ditunjukkan dengan nilai $\mathrm{KHM}_{90}$ pada kadar $0,18 \%$ $\mathrm{b} / \mathrm{v}$. Terdapat efek penghambatan biofilm ekstrak sereh terhadap bakteri Streptococcus mutans, ditunjukkan dengan harga $\mathrm{IC}_{50} 0,137 \%$.

\section{DAFTAR PUSTAKA}

1. Shakh MAR, Ohara-Nemoto $T$, Ono Y, Shimoyama S, Kimura TK, Nemoto K. In vitro processing of glutamylendopeptidaseproenzymes from Enterococcus faecalisand importanceof $\mathrm{N}$-terminal residue in enzyme catalysis, Advances in Biochemistry. 2013; 1(5): 73-80.

2. Sterer N, Rosenberg M. Oral malodor management, breath odors, springer-verlas berlin heidelberg. 2011. H. 18-25.

3. Darby ML, Margaret MW. Dental hygiene: theory and practice, 3rd ed. Elsevier, London. 2010. H. 3,16.

4. Madigan MT, Martinko JM, Brock TD. Brock Biology of Microorganisms. 14th Ed. New Jersey: Pearson Prentice. 2014: 617-619.

5. Eke PI, Dye BA, Wei L. Thornton-Evans GO, and Genco RJ. Prevalence of periodontitis in adults in the United States: 2009 and 2010. J Dent Res. 2012; 91(10): 914-20.

6. Arinda A, Rahardjo P, Triwardani A. Perbedaan efektivitas obat kumur yang mengandung cengkeh dengan obat kumur chlorexidine 
gluconat $0.2 \%$ dalam menghambat pembentukan plak. Orthodontic Dental Journal. 2012; 01(01): 22-25.

7. Diah K. Kontrol plak kemikal dalam pencegahan gingivitis dan periodontitis. Periodontic Journal. 2012; 01(02): 1-6.

8. Raina L. Ensiklopedi tumbuhan berhasiat obat. Jakarta: Salemba Medika. 2011; 13-19.

9. Bassolé I HN, Lamien-Meda A, Bayala B, Obame LC, Ilboudo AJ, Franz C, Novak J, Nebié RC, Dicko R. Chemical composition and antimicrobial activity of Cymbopogoncitratus and Cymbopogongiganteusessential oils alone and in combination. Phytomedicine. 2011; 18: 1070-1074.

10. Jafari B, Amirreza E, Babak MA, Zarifeh $\mathrm{H}$. Antibacteria Activities of Lemon Grass Methanol Extract and Essence Pathogenic Bacteria. American-Eurasian J. Agric and EnvironSci. 2012; 12(8): 1042-1046.

11. Reveny J. Daya antimikroba ekstrak dan fraksi daun sirih merah (Piper betle Linn.). Sumatra Utara: Jurnal IImu Dasar. 2011; 12(1): 6-12.

12. Astuti SM. Skrining fitokimia dan uji aktifitas antibiotika ekstrak etanol daun, batang, bunga dan umbi tanaman binahong (anredera cordifolia (ten) steenis. Balai Besar Pengujian Mutu Dan Sertifikasi Obat Hewan (BBPMSOH). Bogor. Dan Fakulti Kejuteraan Kimia, Universiti Malaysia Pahang. Pahang. 2011.

13. Meena AK, Goyal R, Subraya BG, Kamath S, Anand KM, Aggrawal M. A novel anti-oxidant lemon grass oil mouth wash - a clinical trial. Asian J ExpBiol Sci. 2011; 2(3): 482-6.

14. Radafshar G, Mahboob F, Kazemnejad E. A study to assess the plaque inhibitoryaction of herbal-based tooth paste: a double blind controlled clinical trial. Journal of Medicinal Plant Research. 2010; 4(12): 1182-6.
15. Rosyita A. Formulasi dan studi efektivitas sediaan gel antiseptik tangan dari minyak atsiri daun kemangi (Ocimum sanctum Linn.) terhadap jumlah bakteri tangan siswa SD Kandang Sapi Surakarta sebagai solusi alternatif pencegahan penyakit diare, PKM-P, Fakultas Farmasi, Universitas Sebelas Maret. 2012.

16. Bhowmik N. Dental plaque "Unveiling the biofilm inside". e-Journal of Dent. 2012; 2(1): 119.

17. Tortora J, Gerard J, Funke BR, Case CL. Microbiology an introduction. 10th Edition. Pearson Education. San Fransisco. 2010: 300-301.

18. Osso D, Kanani N. antiseptic mouthrinses: an update on comparative effectiveness, risks and recommendations. The Journal of Dental Hygiene. 2013; 87(1): 12.

19. Chetrus V, lon IR. Dental plaque-Classification, formation and identification. Int Jof Medical Dent, 2013; 3(2): 139-43.

20. Miletis I, Baraba A. Aetiological factors for susceptibility: the location (number, location, activity) and the plaque (identification tools, scoring). J of Minimum Intervention in Dent, 2011; 4(2): 13-6.

21. Rinidar $M$, Isa $T$, Armansyah. Nilai Inhibition Concentration (IC50) Ekstrak Metanol Daun Sernai (Wedelia biflora). Jurnal Medika Veterinaria. 2013; 7: 8-12, 0853-1943.

22. Madhuri S, Gopind P, Karuna SV. Antioxidant, immunomodulatory and anticancer activities of emblicaofficinalis: an overview. International Research Journal of Pharmacy. 2011; 2(8): 38-42.

23. Agoes A. Tanaman obat Indonesia. Salemba Medika, Jakarta. 2010: 55.

24. Kukreja BJ, Dodwad V. Herbal mouthwashes-a gift of nature. Int J Pharm Bio Science. 2012; 3(2): 46-52. 